\title{
Insufficient Industrialization, Delayed Business And Economics Curricula, And Low Economic Development In Pre-1960 Brazil
}

John D. Theodore, Ph.D., DBA, Ph.D., CMC, President, JDT Management Consultants, Florida, USA

\begin{abstract}
The purpose of this article is to indicate that curricula in business administration and economics in the higher educational system of Brazil were not adequately introduced until the 1960s and that the absence of such curricula contributed to the delay of the economic development of the country.

The Portuguese used Brazil as a source of raw materials and for the exportation of agricultural products to Europe. After the independence of the nation in the early 1800s, the large land owners and farmers resisted industrialization in order to perpetuate their power and safeguard their economic and social interests. Due to the lack of industrialization, there was no need to introduce curricula in business and economics. In the 1960s, Brazil witnessed a great movement toward industrialization and economic development in order to compete favorably on an international basis and to confront the economic progress of the Soviet Union and Cuba within the American hemisphere. For this reason, a large number of universities were established, most of which started to offer curricula in economics and business in order to prepare the country's manpower to assume managerial and leadership positions in the areas of commerce and industry and thus contribute to the economic development of that nation.
\end{abstract}

Keywords: Economics And Business Curricula; Higher Education; Industrialization; Industrialization Movement; Agricultural Brazil; Portuguese Colony; Ruling Classes; Jesuits; Corporations; Small Business Enterprises; A Universidade Do Trabalho; Communist Economic Challenge

\section{INTRODUCTION}

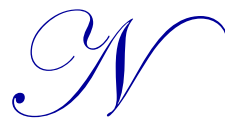

ations like England, Germany, and the United States introduced curricula in economics and business administration in higher education beginning in the latter part of the 1800 s because these curricula were needed for the commensurate education of the human factor in their advancing industrial and commercial enterprises, thus assisting the economic development of such nations.

The major reasons for the delay of both industrialization and the introduction of business and economics curricula in Brazil were the political, economic, and social power centers of the country, supported by the large land owners and farmers who insisted that the nation was better off as an agricultural state rather than an industrial one.

Industrialization And Education In Brazil (1549-1960)

Brazil was an agricultural nation from its inception and provided agricultural exports to Europe and natural resources to the Portuguese metropolis. Sugar, coffee, and other agricultural products were the chief economic elements of the Brazilian economy for over three centuries (Goldberg, 2012). Abortive attempts to form early industries were opposed by the ruling land owners and farmers who controlled the economy. Toward the end of the 1800 s, embryonic textile industries were formed. 
Higher education - and education in general - started in Brazil when the first Roman Catholic clergy arrived in 1549. These were Jesuits whose goal was to educate the population of this Portuguese colony in the American hemisphere. During the next two centuries, the Jesuits formed the Brazilian educational system, including higher education. After two hundred years of hard work, they were expelled from Brazil for political reasons.

The first educational institution to be established in Brazil was started in 1549 by Father Manoel Nobrega. It was the Real Colegio da Bahia with strictly religious curricula. Several decades later, philosophy, humanities, and letters were additional curricula taught by such institutions (Domingos, 1956). From the above cited period to the 1800 s, a number of additional colleges were established, none of which had a single curriculum in economics or business. Between 1800 and 1822, under the auspices of the Emperor Dom Joao VI of Portugal who had moved to Brazil, a military academy, a school of law, and a school of medicine were established. In the next two decades schools of pedagogy were formed for elementary school teachers.

In nineteenth century Brazil, "large corporations were very limited in number and individual firms were limited in size and economic impact" (Ridings, 1994, p. 8). The first large-size corporation, the National Steel Company, was established in 1942 and was totally owned and operated by the government (Becker \& Egler, 1992). Limited sized business organizations, which still exist in Brazil and other parts of Latin America, did not operate on economies of scale and their contribution to the overall economy were - and still are - very limited (Theodore, 2009). Therefore, curricula in business and economics were not needed.

There were no "universities in Brazil until the administration of President Vargas in the early 1930s" (Roett, 2010, p. 150). It was during this period that Brazil witnessed a strong movement toward the establishment of more educational institutions, including universities such as the Universities of Rio de Janeiro, Minas Gerais, Porto Alegre, and Sao Paulo. Such universities were organized in a manner similar to their counterparts in developed countries (Filho, 1967). However, none of them had curricula in economics and business. During the same period, the United States and the United Kingdom had a multitude of colleges and universities offering business and economics curricula to the general public.

The economy of Brazil continued to remain agricultural and underdeveloped during the first sixty years of the twentieth century. The private business sector was limited and unemployment was high. Most of the industrialists before and during the above-cited period were importers who, "at a certain stage of their activities, found it worthwhile to produce goods domestically instead of importing them. This was especially true in the textile industry" (Baer, 2008, p. 27). Those importers/embryonic industrialists were entrepreneurs and had no need for educated and trained managers in business and economics curricula; therefore, there was no need for the existence of such curricula in higher education.

Traditional university curricula were open to the elite members of the country, whereas economics and business curricula had not appeared yet (Grande, 1944). Starting in 1943, special elementary school curricula were implemented dedicated to commercial, technical, and industrial education (Arcanjo \& Hanashiro, 2010).

The emerging industrial class at the end of the second quarter of the past century vehemently opposed the idea of Brazil remaining an agricultural nation and started to create the first modern industrial infrastructure and introduce business and economics curricula in the newly established institutions of higher learning (Skidmore, 2010). The landmark of the introduction of business and economics curricula in higher education started with the formation of A Universidade do Trabalho established in 1957. It was the first institution of higher learning that opened its doors to the masses and provided curricula needed for the commercial, industrial, and economic development of the country. The government, having taken this initiative, "modified the destiny of Brazil by opening the way to prosperity and well-being of its people" (Grande, 1965, p. 38).

The massive introduction of curricula in economics and business started in Brazil in the 1960s in order to accelerate economic development and to confront the influx of the Communist economic challenge emanating from the Soviet Union and Castro's Cuba. Today Brazil has a large number of institutions of higher learning most of which provide curricula in business and economics for the education of the country's commercial and industrial manpower (Theodore, 2012). Graduate curricula in most university studies-including business and economics- 
were introduced in 1965 (Arcanjo \& Hanashiro, 2010). Brazilian universities have been undergoing continuous progressive restructuring conducive to offering better curricula in all areas (Cunha, 1988), including business and economics. The men and women who have graduated with specializations in business and economics are contributing toward the industrial, commercial, and economic development of their nation. However, the lack of early industrialization and economics and business curricula in higher education in the past are partly responsible for the current absence of a strong industrial infrastructure and a well-balanced economy in comparison to the wellbalanced economies and strong industrial infrastructures of the United Kingdom, United States, and Germany.

\section{CONCLUSIONS}

Brazil, the largest nation in Latin America, had an agricultural economy from the time of its inception in in the early 1500s to the 1960s. The Portuguese metropolis used Brazil as a source of raw materials and for the exportation of agricultural products to Europe. After the independence of the nation in the early 1800s, the large land owners and farmers resisted industrialization of the country in order to perpetuate their power and safeguard their economic and social interests. Due to the lack of industrialization, there was no need to introduce curricula in business and economics similar to the ones introduced by the United States, England, and Germany at the end of the 1800 s in order to commensurately educate their citizens to assume commercial and industrial management and leadership positions conducive to the economic development of such nations.

In the 1960s, Brazil witnessed a great movement toward the industrialization and the economic development of the country in order to compete actively on an international basis and confront the economic challenge of the Soviet Union and Cuba within the American hemisphere.

\section{AUTHOR INFORMATION}

John Theodore is the holder of a Ph.D. degree in Administration and Latin American Studies from the University of Kansas; a Ph.D. in Management from the Aristotelian University in Greece, European Union; and a D.B.A. in International Business from the University of South Africa. He has been teaching and consulting for four decades, both domestically and internationally. He is a visiting professor in various foreign universities. Dr. Theodore is the president of JDT Management Consultants in Clearwater, Florida, specializing in management, organization, strategy, international business, human resources, organizational development, and educational administration. He is a certified management consultant (CMC) certified by the Institute of Management Consultants in Washington, D.C.

\section{REFERENCES}

Arcanjo, F., \& Hanashiro, M. (2010). A historia da educacao no Brazil. Sao Paulo: Biblioteca de 24 horas, Seven System Internacional, Ltda.

Baer, W. (2008). The Brazilian economy: Growth and development $\left(6^{\text {th }}\right.$ ed.). Westport, CT: Praeger Publishers.

Becker, B. K., \& Egler, C. (1992). Brazil: A new regional power in the world economy. New York: Cambridge University Press.

Cunha, L. A. (1988). A universidade reformada. Rio de Janeiro: Francisco Alves.

Domingos, M. (1956). Inacio de Loyola e Portugal. Lisboa: Broteria.

Filho, L. (1967). Organizacao e administracao escolar ( $2^{\text {nd }}$ ed.). Sao Paulo: Edicoes Melhoramentos.

Goldberg, J. L. (2012). Trade and institutions in the Medieval Mediterranean: The Geniza merchants and their business world. New York: Cambridge University Press.

Grande, H. (1944). A Politica do Trabalho. Porto Alegre: Edicoes a Nacao.

Grande, H. (1965). A Universidade do Trabalho. Rio de Janeiro: Departmento de Imprensa Nacional.

Ridings, E. (1994). Business interest groups in nineteenth-century Brazil. New York: Cambridge University Press.

Roett, R. (2010). The new Brazil. Washington, DC: The BrookingsInstitution Press.

Skidmore, T. E. (2010). Brazil: Five centuries of change ( $2^{\text {nd }}$ ed.). New York: Oxford University Press.

Theodore, J. (2009). Organizational size: A key element in the development of private enterprises in the less developed countries: The case of Ecuador. International Business \& Economics Research Journal, 8(7), 45-49.

Theodore, J. (2012). Culture and the development of management. Richmond, CA: Lyseis Public Policy Publishing. 


\section{NOTES}

